\title{
Poverty and Property Rights in the Developing World: Not as Simple as We Would Like
}

Jon D. Unruh

McGill University

Significant attention is currently focused on the economic potential of the informal, undocumented property held by the poor in developing countries. Such property (particularly that associated with land) occupied but not formally owned, is thought to amount to considerable capital--much larger than the total investment in, and foreign assistance to, the developing world over the past couple of decades. This notion, much advanced by the Peruvian economist Hernando de Soto*, holds that with such potential, the opportunity offered by individualized formal title would appear to be substantial. To the degree that this potential is compared to requests for aid and investment by poor countries suggests that recipient countries clearly must be looking in the wrong place for infusions of capital. And so it would appear we have at last found the magic equation for development_hardly. Much about the idea seems to revolve first around land and its potential for collateral, but more fundamentally around issues of law--given that those who occupy lands are very frequently unable to prove ownership by way of the formal title that lending and other civil institutions require. The legal problem concerns the ongoing disconnect between formal state law, and the customary or traditional law which governs how a great deal of the world's poor intersect with property. The former allows assets to be fungible and used as such by individuals; but the latter has evolved under a different tenurial logic--the maintenance and security of community and lineage connection to land in an often risky physical, social, and political environment.

The explanation advanced by de Soto and others for this disconnect is that formal law in much of the developing world has little to do with what most people are actually doing 'on the ground.' In countries afflicted by this disconnect, there can be little opportunity or willingness on the part of the state to formalize customs and norms that reflect ongoing rights and obligations about land. In this regard, so the argument goes, how American formal property law evolved over time to reflect actual processes of land use, claim, and disputing as the country was settled, is thought to be an important example with regard to what works.

\section{Tenurial Purpose}

But the American example captures a primary problem in the capital - property rights argument--and there are several. First, how the American pioneer intersected with lands and how this evolved into, or merged with formal law is much less relevant to the situation of developing countries than is how the property rights systems of Native Americans intersected with formal law, however 'evolving' the latter might have been. With significantly different conceptual foundations, customary law and formal law in developing countries (the latter usually inherited from European colonial law) have less to do with each other than the 'on the ground' activities that migrants and settlers (around the world) have employed (and employ-Brazil) which merged successfully with subsequent formal law. The ways in which settlers and migrants intersect with the land are very much more amenable to formal law than inplace, functioning indigenous tenure regimes. In many instances--including the American example--settlers can share, or come to share, a similar tenurial logic reflected in state law, in some cases because the state facilitates settlement. As a result, the sociocultural distance is less, and formal and informal institutions can be mutually supportive. And where the tenurial logic between the state and migrants differ significantly, migrants can be much more willing to adapt to new tenure systems (particularly when there is little connection to local customary systems), because ongoing social relations about land associated with pre-migration customary tenure regimes are largely disrupted by the migration event. Hence institutions of membership, reciprocity, sanction, and obligation involving land as a community level phenomenon are no longer operative, and access to land must be pursued by other means.

Second, significant aspects of customary tenure are bound up in notions of property rights that facilitate risk reduction at the group level, as opposed to enabling capital for the individual the latter essentially a risk-taking endeavor. State systems, institutions, and alternatives having to do with personal, food, and livelihood security and insurance that inspire confidence would go a long way in enabling risk taking, and the attractiveness of opportunities associated with land as a good. However not only are these arrangements variably available, expensive, corrupt, and beyond the financial and educational means of most in the developing world (where they are not lacking), they can be quite difficult to put together for whole populations, requiring capacity and resources that many countries are unable to afford. Moving from community or lineage held land via title to individually held land would in many cases destroy customary institutions for this security and insurance. This is where the de Soto argument is significantly uninformed. And then there is the issue of homeland or home territory to which identity based attachments to land can run very deep for very uneconomic reasons. While the Middle East is one of the more vivid examples of this, there are many. 
Third, attempts at incorporation of aspects of indigenous tenure regimes into formal law, finds that much in customary law can be fluid, reflecting change in a variety of social, political, and economic variables, including capricious decision-making by leadership. The goals of formalized property laws are otherwise. Such laws are much less subject to change, hence their predictability, wide application, and value in operationalizing capital and other aspects of property associated with land as a commodity.

\section{Connecting Formal and Customary Property Law}

Given the pervasiveness of customary law (which in Africa is how most people get by) and the realization that attempting to replace customary law with formal law does not legislate human behavior into or out of existence, the problem is more complex than giving people title and assuming that individualized tenure and land markets will follow. Numerous large and expensive projects in Africa attempting such a replacement have failed. Just as attempts to create a land market, and use land as collateral have failed due to the inability of lending institutions to extract defaulted land from the community, lineage, ethnic, religious, or geographic group that in reality holds and administers it.

The problem at this point in history for developing countries is larger and more problematic than just fashioning local notions of property into a set of uniform enforceable laws along the lines of the capital-poverty-property rights argument. It is now the added dilemma of attempting to connect in a meaningful way, in-place, formal, Europeanderived property laws (which won't be going out the door any time soon given how they are favored by urban elites), and customary laws and activities which are bound up in ongoing social relations about land, and which service important social needs that individualized title alone cannot replace. Any 'translation' of local reality into formal law must also have continued meaning in customary law. Such translation can be difficult given the inability of many formal property laws to deal effectively with parol (oral) evidence as proof of ownership, and in disputing, etc., due to the perceived necessity to preserve the integrity of the document in matters relating to property. Of course verbal or testimonial evidence is in most cases all that customary communities in developing countries posses.

To move from property tied to community, lineage, and geography (identity essentially) to something based on the individual and able to take advantage of aspects of capital as we presently understand the opportunities, would be a significantly long and arduous process. What will be needed in the end are not just attempts at formalizing aspects of customary law, as de Soto and colleagues suggest, but as well a change in concepts dear to formal law, such as the integrity of the document and the static nature of rules.

Much importance is placed on coming up with the 'right' way to do property rights in the developing world. To the degree that 'right' means Western and homogenized, accomplished by legislation, ignores fundamental realities in the way much of the world works with property. de Soto and colleagues put great energy into extolling the virtues of the property _ capital nexus for whom it already works. And the thinking seems to be, that it's just a matter of joining the club. We all want a quick fix for the world's woes, unfortunately this isn't one.

*Hernando de Soto (2000) The Mystery of Capital: Why Capitalism Triumphs in the West and Fails Everywhere Else. Basic Books, New York 